\title{
Experimental infection of Leishmania (L.) chagasi in a cell line derived from Lutzomyia longipalpis (Diptera:Psychodidae)
}

\author{
Felio J Bello/ ${ }^{+}$, Astrid J Mejía, María del Pilar Corena*, Martha Ayala**, \\ Ladys Sarmiento**, Claudio Zuñiga***, María T Palau***
}

Laboratorio de Entomología, Biología Celular y Genética, Departamento de Ciencias Básicas, Universidad de La Salle, Bogotá DC, Colombia *Whitney Laboratory for Marine Bioscience, University of Florida, St. Augustine, FL, US **Instituto Nacional de Salud de Colombia, Bogotá DC, Colombia ***Facultad de Veterinaria, Universidad de Chile, Santiago de Chile, Chile

The present work describes the in vitro infection of a cell line Lulo, derived from Lutzomyia longipalpis embryonic tissue, by Leishmania chagasi promastigotes. This infection process is compared with a parallel one developed using the J774 cell line. The L. chagasi MH/CO/84/CI-044B strain was used for experimental infection in two cell lines. The cells were seeded on glass coverslips in 24-well plates to reach a final number of $2 \times 10^{5}$ cells/well. Parasites were added to the adhered Lulo and J774 cells in a 10:1 ratio and were incubated at 28 and $37^{\circ} \mathrm{C}$ respectively. After 2, 4, 6,8 , and 10 days post-infection, the cells were extensively washed with PBS, fixed with methanol, and stained with Giemsa. The number of internalized parasites was determined by counting at least 400 cultured cells on each coverslip. The results showed continuous interaction between L. chagasi promastigotes with the cell lines. Some ultrastructural characteristics of the amastigote forms were observed using transmission electron microscopy. The highest percentage of infection in Lulo cells was registered on day 6 post-infection (29.6\%) and on day 4 in the J774 cells (51\%). This work shows similarities and differences in the $\mathrm{L}$. chagasi experimental infection process in the two cell lines. However, Lulo cells emerge as a new model to study the life-cycle of this parasite.

Key words: Leishmania chagasi - Lulo cell line - J774 cell line - infection percentages - parasitophorous vacuoles

Leishmania chagasi is a causative protozoan parasite of American visceral leishmaniasis (Grimaldi \& Tesh 1993). The disease is endemic in some regions of Colombia (Corredor et al. 1989, 1990) and throughout all the South and Central America (Grimaldi \& Tesh 1993, Tanner 1996); the parasite has been isolated from hosts, reservoirs and sand fly vectors. This species, as well as other species belonging to the Leishmania genus, develops through a digenetic life cycle consisting of an extracellular promastigote form that develops and multiplies in the alimentary tract of the sand fly vector and an intracellular amastigote form that resides and multiplies inside the infected mammal host's macrophages. Clinical and experimental evidence indicates that vector, parasite, and host factors influence the evolution and outcome of the infection caused by Leishmania parasites (Grimaldi \&Tesh 1993).

Promastigotes are routinely cultured in vitro using cell free medium; such easily obtained media have also been used to induce promastigote transformation to amastigotelike forms in response to elevated temperature and acid pH (Hendrick et al. 1978, Hunter et al. 1982, Pan 1984, Zilberstein et al. 1991, Bates et al. 1992, Bates \& Tetley 1993, Zilberstein \& Sahapira 1994, Bates 1994, León et

Financial support: Colciencias (grant 1243-05-12416), Universidad de La Salle, Instituto Nacional de Salud de Colombia

+Corresponding author. E-mail: fbello@urosario.edu.co

Received 2 December 2004

Accepted 24 August 2005 al. 1995, Hodgkinson 1996, Saar et al. 1998). It has been shown that these axenic amastigotes closely resemble animal-derived amastigotes. Leishmania in vitro differentiation, maturation, and replication has also been achieved in both macrophage cell cultures (Chang \& Dwyer 1978, Chang 1979, Pearson et al. 1981, Aikawa et al. 1982) and non-macrophage cell lines, mainly in fibroblast cultures (Mattock \& Petters 1975, Chang 1978, Dedet et al. 1983, Schwartzman \& Pearson 1985, Corte-Real et al. 1995, Hervás Rodrigues et al. 1996, Pessotti et al. 2004). However, in spite of current support, cell lines and cell free media being available for transforming the life cycle of diferent Leishmania species, there is no information available regarding this process in cell cultures obtained from phlebotomine sand fly vectors.

The present study describes the in vitro infection of Lulo cell line (Rey et al. 2000) by L. chagasi promastigotes and some ultrastructural characteristics regarding the parasite's interaction with these cells were determined. This cell line was derived from L. longipalpis embryonic tissue, which is the main vector of $L$. chagasi in its natural environment. The experimental infection of Lulo cell line was compared to infection of J774 cell (Ralph et al. 1975).

\section{MATERIALS AND METHODS}

Parasites - The strain of L. chagasi, $\mathrm{MH} / \mathrm{CO} / 84 /$ Cl-044B, was isolated from a human case of visceral leishmaniasis in Quipile, Cundinamarca, Colombia. This strain has been maintained by periodic inoculations of promastigotes in Syrian golden hamsters (Mesocricetus auratus) in the parasitology laboratory at the National Institute of Health in Colombia. L. chagasi amastigotes were recovered from the spleen of infected hamsters as previously described (Duque et al. 1988). Promastigotes 
were obtained by in vitro conversion of amastigotes at $24^{\circ} \mathrm{C}$ in Drosophila Schneider medium, suplemented with $20 \%$ heat-inactivated fetal bovine serum (FBS), $100 \mathrm{U} /$ $\mathrm{ml}$ of penicillin and $100 \mu \mathrm{g} / \mathrm{ml}$ of streptomycim. Some $L$. chagasi promastigotes cultures were stored in liquid nitrogen. The promastigotes used for infecting J774 and Lulo cells were day-7 stationary phase cultures from the second passage in culture. These promastigotes were washed in phosphate-buffered saline (PBS), pH 7.2, before being used in cell-parasite coculture experiments.

Cell lines - The Lulo cell line, obtained from embryonic tissue of L. longipalpis and previously established (Rey et al. 2000), was cultured in a 1:1 mix of L15 (Leibovitz 1963) and Grace media (Grace 1962) supplemented with $10 \%$ FBS, pennicillin $(100 \mathrm{U} / \mathrm{ml})$ and streptomycin $(100$ $\mu \mathrm{g} / \mathrm{ml})$. The cells were incubated at $28^{\circ} \mathrm{C}$, without $\mathrm{CO}_{2}$. The J774 cell line (Ralph et al. 1975), isolated from reticulated cells from Balb/c mice (kindly provided by $\mathrm{Dr}$ Marcela Camacho del Centro Internacional de Física de la Universidad Nacional de Colombia) was maintained in RPMI medium, 1640 (Sigma), with FBS (15\%) and gentamycin $(1 \%)$ and incubated at $37^{\circ} \mathrm{C}$ with $5 \% \mathrm{CO}_{2}$. The confluent monolayers, in both cell lines, were mechanically removed with the help of rubber policemen. The cells were harvested in log phase of growth. To prepare cells for infection, $\mathrm{J} 774$ and Lulo cells were put separately into $15 \mathrm{ml}$ centrifuge tubes to prepare them for infection and were then washed by centrifuging for $10 \mathrm{~min}$ at $400 \times \mathrm{g}$ with each culture media mentioned above.

Cell line infection - Cells from each cell line were seeded on glass coverslips inside 24 well-plates (Corning) to a final number of $2 \times 10^{5}$ cells per well. Twenty- four hours after adhesion and growth on the coverslips, the semiconfluent monolayers were infected with promastigotes in stationary phase using 10 parasites per cell. Infected Lulo and J774 cells, separately in different plates, were incubated at $28^{\circ} \mathrm{C}$ without $\mathrm{CO}_{2}$ and at $37^{\circ} \mathrm{C}$ with $5 \% \mathrm{CO}_{2}$, respectively. Some coverslips were removed in early assays after 1,2, and $3 \mathrm{~h}$ of incubation in coculture; the preparation was fixed with methanol and stained with giemsa. The number of promastigotes adhered per cell in both cell lines was determined by counting 200 cells per coverslip in duplicate cocultures. Following $12 \mathrm{~h}$ incubation, non-internalized promastigotes were removed by washing with PBS and incubated using the same culture media. The coverslips with the attached infected cells were removed after 2, 4, 6, 8, and 10 days post-infection, washed with saline solution, fixed and stained as described earlier. Cells were observed and photographed using a light microscope with an Olympus microphotographic system, $400 \times$ to $1000 \times$ magnification. These assays were repeated three times to determine the experimental data's reproducibility. The number of infected cells and the average number of promastigotes per cell was calculated by counting at least 400 cells per coverslip. Results were expressed as the percentage of infected cells and infection index. This last parameter was obtained by multiplying the infection percentage by the average number of intracellular amastigotes per cell (Lonardoni et al. 2000). Differences between experimental groups were determined by using the Student's t-test. Differences at $P<0.05$ were regarded as significant.

Amastigote to promastigote differentiation assays Lulo cells (final number of $2 \times 10^{6}$ cells $/ \mathrm{ml}$ ) were seeded in $12.5 \mathrm{~cm}^{2}$ flasks, previously containing $4 \mathrm{ml}$ of fresh L-15/Grace medium and supplemented as described above. These cells were incubated at $28^{\circ} \mathrm{C}$; semiconfluent monolayers were reached after of subculturing for 3 days. The Lulo cells were then infected with $L$. chagasi promastigotes in stationary phase at a 10:1 an parasite:cell ratio and incubated again in the same conditions for $24 \mathrm{~h}$. The monolayers were washed with PBS to remove noninteriorized promastigotes and fresh medium was added. However, to assure total removal of non-internalized promastigotes, new washes were carried out each day with PBS and fresh medium was added. The infected monolayers were gently scraped on day 6 post-infection and the content of the flasks was vigorously pipetted to dissociate the cells. These cells were then seeded in NNN medium and incubated to $26^{\circ} \mathrm{C}$. The cocultures were observed daily with an inverted microscope to identify transformed promastigotes. The previous technique was used for the J774 cells; however, the maintenance conditions described above were for these cells.

Transmission electron microscopy - Infected J774 cells and Lulo cells (each kept separate 6-well plates) were fixed in situ for $1 \mathrm{~h}$ in $2.5 \%$ glutaraldehyde in $0.1 \mathrm{M}$ sodium cacodylate buffer, $\mathrm{pH} 7.2$ and sucrose. The cells were rinsed with the same buffer, postfixed for $1 \mathrm{~h}$ with $1 \%$ osmium tetroxide diluted in the same buffer, washed again, dehydrated in a graded series of ethanol and embedded in epon-araldite resin. Ultra-thin sections were obtained using an ultramicrotome LKB and the sections were stained with aqueous uranyl acetate and lead citrate. The grids were observed by transmission electron microscope (Zeiss EM110).

\section{RESULTS}

Light microscopy - The Lulo cells showed higher number of promastigotes adhered compared with values obtained from J774 cells (Fig. 1). Moreover, with time of incubation tested ( 1 to $3 \mathrm{~h}$ ) there was an increase in number of promastigotes adhered per cell in both cell lines. Twelve hours post-infection, we detected a strong attachment of L. chagasi promastigotes and Lulo cells, evidenced by parasite resistance becoming detached during PBS washes. New PBS washes were performed during the folowing days until complete removal of the parasites on the 3rd day post-infection. By contrast, promastigotes were easily removed from the $\mathrm{J} 774$ cells during the same interval of time, no additional washes being necessary. During the time taken for these experiments, observations on days $2,4,6,8$, and 10 post-infection showed amastigote forms of the parasite and completely stained structures inside the parasitophorous vacuoles (Fig. 2A). However, motile parasites (promastigote-like forms) were observed during days 2, 4, and 6 in some Lulo cells vacuoles (Fig. 2B). Non-promastigote-like forms were observed in J774 cells. The Table shows the values obtained in vitro infection with $L$. chagasi in the selected cell lines. Percentages and 
infection index demonstrated that Lulo cells presented a gradual increase from day 2 to day 6 , where they reached their maximum peak (29.6\%), with a decrease around day 8 and lower numbers around day 10 (Fig. 3). The percentages and index of infection in the $\mathrm{J} 774$ cell line were higher compared to those for the Lulo cells (Table). However, the maximum value was registered on day $4(51 \%)$.

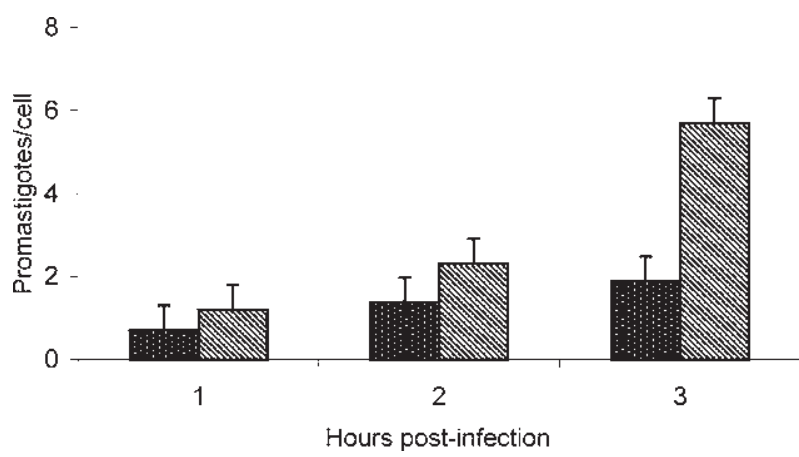

Fig. 1: interaction between promastigotes of Leishmania chagasi with cell lines tested: Lulo (bars with diagonal lines) and J774 (dark bars with clear points). Adhered cells were incubated with $L$. chagasi at 1:10 ratio at $28^{\circ} \mathrm{C}$ (Lulo) and $37^{\circ} \mathrm{C}(\mathrm{J} 774)$ for $3 \mathrm{~h}$. Results are expressed as number of attached promastigotes per cell. Mean \pm SD of three separate experiments done in duplicate.
Amastigote to promastigote differentiation - Promastigotes began to appear in the cocultures after three days post-infection of Lulo cells, amastigotes to promastigotes differentiation was completed within 7 days. J774 cell differentiation was slower, beginning 6 days post-infection.

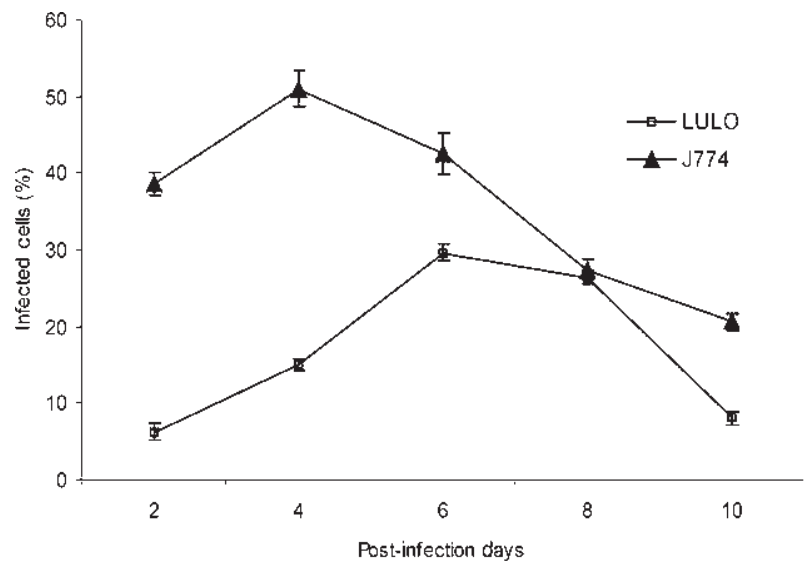

Fig. 3: comparison of the in vitro infection between Lulo cells and J774 cells by Leishmania chagasi.
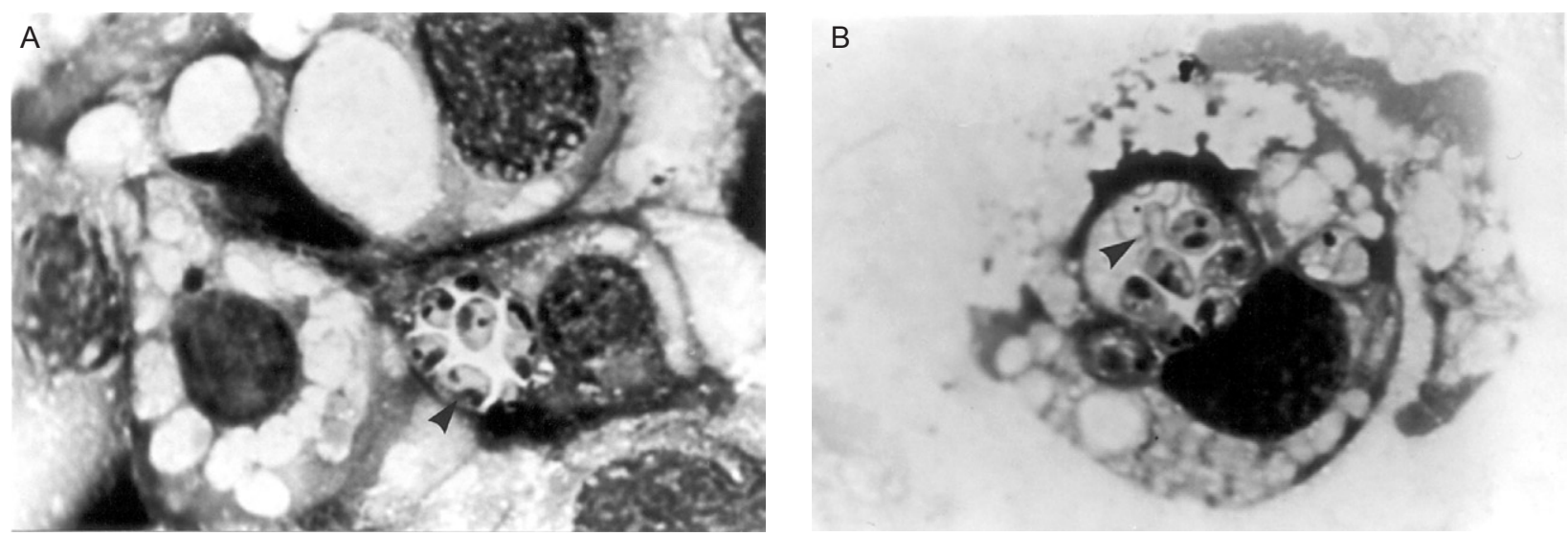

Fig. 2: light micrographs of Lulo cells infected with Leishmania chagasi. A: amastigotes (arrowhead) within a parasitophorous vacuole in Lulo cell cytoplasm 2 days after infection, showing the nucleus and kinetoplast in each of them. $(\times 1000)$; B: promastigote-like forms inside a parasitophorous vacuole in a Lulo cell, 4 days post-infection. The flagellums of one of them can be seen in detail (arrowhead). $(\times 1000)$.

TABLE

Mean data obtained of the Lesihmania chagasi experimental infection process of the two cell line

\begin{tabular}{lrrrrrr}
\hline & \multicolumn{2}{c}{ Lulo } & & \multicolumn{2}{c}{ J774 } \\
$\begin{array}{l}\text { Day } \\
\text { index }\end{array}$ & Infection percentage & Amastigotes/cell & Infection index & Infection percentage & Amastigotes/cell & Infection \\
\hline 2 & $6.2 \pm 1.1$ & 2.6 & 16.12 & $38.6 \pm 1.5$ & 5.4 & 208.4 \\
4 & $15 \pm 0.7$ & 4.6 & 69 & $51 \pm 2.3$ & 10.0 & 510 \\
6 & $29.6 \pm 1.1$ & 6.4 & 189.44 & $42.6 \pm 2.7$ & 18.6 & 792.36 \\
8 & $26.4 \pm 0.8$ & 9.3 & 245.52 & $27.4 \pm 1.3$ & 13.8 & 378.12 \\
10 & $8 \pm 0.8$ & 1.9 & 15.2 & $20.6 \pm 1.1$ & 6.1 & 125.66
\end{tabular}

Each value is the mean of three experiments done in duplicate; \pm standard error; differences between Lulo cells and J774 cells were significant at $p<0.05$, except for day 8 when there were no significant differences in infection percentage. There was differences among days in each cell lines. 
Transmission electron microscopy - Electron micrographs demonstrated L. chagasi promastigote form interaction with Lulo cell membrane 2 days post- infection, without a preferential orientation. The parasites adhered by the flagellar tip or the posterior pole. The parasites' lateral adherence to the Lulo cell surface was also observed (Fig. 4A). Samples taken from Lulo cells 3 days post-infection, presented amastigotes in a typical narrow parasitophorous vacuole (Fig. 4B). Some cells' organelle ultrastructure (n: parasite nucleus, $\mathrm{N}$ : cell nucleus, and f: flagellum) was clearly visible in this parasite (Fig. 4B). Promastigote-like forms were also observed inside the parasitophorous vacuoles following 4 days interaction with Lulo cells (Fig. 4C). Parasites inside of parasitophorous vacuoles were also visible in $\mathrm{J} 774$ cells 2 days post-infection (Fig 4D).
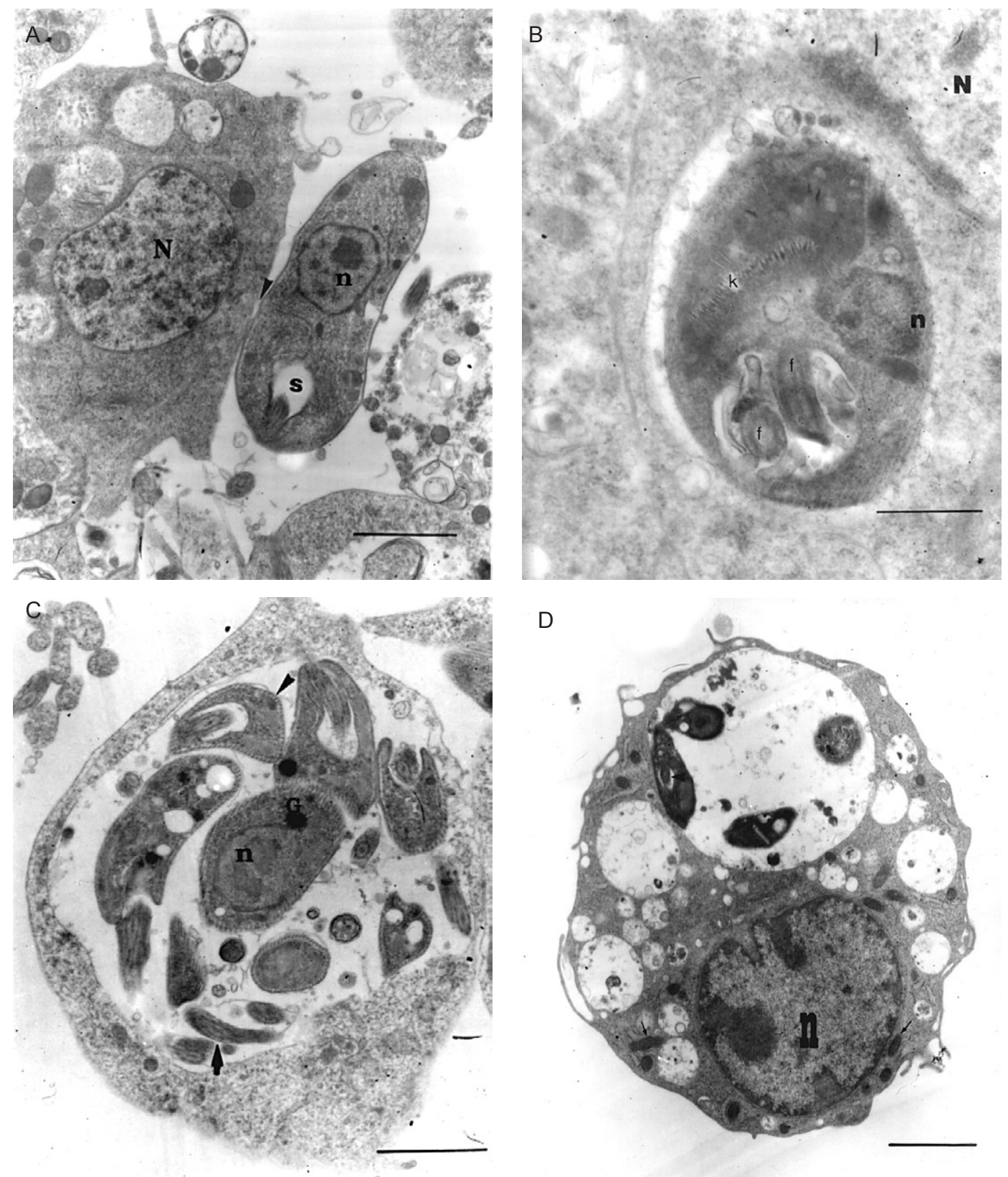

Fig. 4: transmission electron micrographs showing interaction between Leishmania chagasi parasites with J774 and Lulo cells, some parasite and cell ultrastructural characteristics were also observed. A: point of contact between promastigote membrane and the Lulo cell membrane after $48 \mathrm{~h}$ incubation. Parasite adhesion to cell was through the cell body. n: promastigote nucleus; S: flagellar sack; N: Lulo cell nucleus. Bar: 1.5 $\mu \mathrm{m}$; B: ultrastructure of an amastigote localized inside narrow parasitophorous vacuole in a Lulo cell, 3 days post-infection. Two flagella can be seen (f); k: kinetoplast; $\mathrm{n}$ : parasite nucleus; $\mathrm{N}$ : cell nucleus. Barr: $0.3 \mu \mathrm{m}$; C: promastigote-like forms inside of a large parasitophorous vacuole in a Lulo cell after 4 days of interaction. The arrow indicates a segment of the flagellum. n: nucleus; arrowhead: subpellicular microtubules; G: granules. Bar: $1.5 \mu \mathrm{m}$; D: J774 cell with three parasites inside a large parasitophorous vacuole, 2 days post-infection. kinetoplast (k) can be observed in an amastigote and a transversal section shows a flagellum (arrowhead) surrounded by the flagellar sack in another parasite. $\mathrm{n}$ : cell nucleus; mitochondria (arrow). Bar: $2.0 \mu \mathrm{m}$. 


\section{DISCUSSION}

We have demonstrated that Leishmania promastigotes can invade cells derived from embryonic tissues obtained from the phlebotomine sand fly vector and transform into amastigote-like forms inside these cells. L. chagasi presented morphological characteristics when developed inside Lulo cells that allowed parasitic forms to be differentiated during their development in both cell lines, even though J774 cells present macrophage properties. This comparison also revealed some similarities.

Light microscopy revealed that promastigotes present a high affinity for the surface of Lulo cells. Such an observation has been recorded previously (Rey et al. 2000). It was also possible to identify relatively high levels of promastigotes attached to the Lulo cells as well as was demonstrated that the adhesion of the parasite to this cells was maintained during a long period of time. This process was probably enhanced by the favorable conditions provided by the L-15/Grace medium where simultaneous and intense promastigotes replication was observed. The Lulo cells also presented characteristics typical of mixed cultures having pluripotential cells. It is probable that the Lulo cell line may simulate some of the in vitro interaction events that occur between the parasite and the epithelial cells inside the insect's midgut. This observation could explain the parasite's strong adhesion to the Lulo cells. It is possible that this process is an indication of the presence of carbohydrates on the cell surface of the promastigote, similar to those molecules responsible for the adherence of the parasite to sand fly midguts (Sack et al. 1985, 1994, Pimenta et al. 1991, Saraiva et al. 1995, Sacks \& Kamhawi 2001, Fampa et al. 2003). Although, promastigotes adherence to the $\mathrm{J} 774$ cell surface was observed, this phenomenom was present in less proportion, persisting only until removal of the parasites with PBS washes, 12 $\mathrm{h}$ post-inoculation. However, the levels of infection were higher when compared with the values obtained from the Lulo cells. The difference in the adhesion could be attributed to the fact that there exists mechanisms of adhesion caused by similar molecules to the integrins, between the parasite and the Lulo cells, which would explain the necessity of successive washings to remove the adhered parasites. This strong interaction between the parasite and Lulo cells, that would be similar to which happens in the digestive tract of the insect, could lead to the acquisition of the insect molecules which could act like opsonins (Prina et al. 2004), later recognized by the cells of the immune system of the mammalian host. On the other hand, in the case of the J774 cells, due to its characteristics as phagocitic cells, the interaction of parasite-host cell could be similar interactions to those that would happen between molecules presents in the pathogens surface denominated pathogen-associated molecular patterns (PAMPs) and receptors present in the phagocitic cells denominated pattern-recognition receptors (PRRs), during phagocitosis, which would favor the penetration of the parasite to the cells. In previous works, basics and applied (Aikawa et al. 1982, Looker et al. 1986, Bosque et al. 1998, Pelletier et al. 2003), where the interaction between Leishmania parasites and macrophages was evaluated, it was suggested that the adhesion of the parasites with these cells occurs early and persists for a relatively short time before the internalization. It is possible that a similar situation has happened with the infected $\mathrm{J} 774$ cells.

Light microscopy and transmission electron microscopy also revealed that Lulo cells presented amastigotes, individually or in groups within parasitophorous vacuoles. A significant average number of amastigotes per cell was also registered, indicative of the replication process experienced by parasites within these vacuoles, similar to that observed in vitro in other macrophage and fibroblast cell-lines (Mattock \& Petters 1975, Chang 1978, Chang \& Dwyer 1978, Pearson et al. 1981, Aikawa et al. 1982, Dedet et al. 1983, Schwartzman \& Pearson 1985, Corte-Real et al. 1995, Hervás Rodrigues 1996, Pessotti et al. 2004). The increase in L. chagasi infection percentage and infection index in Lulo cells (using light-microscopy), became evident on days 2 and 4, reaching its peak on day 6 , being more or less stable on day 8 (registering a non-significant reduction) and finally descending on day 10 (the lowest point reached in these data sets).

There was a concomitant increase in Lulo cells for the average number of amastigotes per cell over the period of time mentioned above, greatest average occurring on day 8 . The greatest number of promastigotes had probably been internalized during the first $12 \mathrm{~h}$ of interaction. However, due to the fact that many of these parasites remained strongly adhered to the cells and the fact that they could not be removed by washing with PBS during this time, some of these parasites had probably become internalized during subsequent days until the rest of the promastigotes (both in culture medium and those still remaining adhered), had been completely removed by the mechanical action of washing on the 3rd day post-infection. There was a gradual loss of cells in the monolayer from each coverslip on day 4; however, this loss was higher on day 10 , which could explain the strong descent registered in the infection percentage during this day.

A notable characteristic regarding Lulo cells was the presence of promastigote-like forms within parasitophorous vacuoles observed on days 2, 4, and 6 postinfection, similar to that recorded in vitro in P388D cells (Aikawa et al. 1982), when the parasite had been recently internalized inside cytoplasm and was being converted to an amastigote form inside the parasitophorous vacuole. However, the parasite was found as promastigote-like form during advanced days of infection in Lulo cells. Such a phenomenon can be explained by taking the following factors into account: (1) the temperature at which infected cells were maintained $\left(28^{\circ} \mathrm{C}\right)$ was less than the temperature experienced by parasites in natural infection in vertebrate macrophages. This situation could eventually prolong the process of some promastigotes transforming themselves into amastigotes, even though such process was not simultaneously observed in all of them on the same days of infection as we observed within parasitophorous vacuole amastigote forms. This was probably due to the latter parasites being better adapted to cell-culture environmental conditions, thus being able to achieve the conversion; (2) it is probable that promastigote has invaded host cell later on and the event had thus been registered, if we accept the 
argument that parasites were being continuously internalized during advanced days of infection as a valid argument according to the explanation stated above regarding late intracellular penetration of pro-mastigotes strongly adhering to cells; (3) it is probable that this phenomenon was due to a combination of the previous factors.

Infection percentages were higher in J774 cells compared to Lulo cells, due to the former presenting macrophage characteristics with cells of phagocytic ability (Ralph et al. 1975, Papadimitriou \& Ashman 1989). These cells were also physiologically adapted as parasite host cells. However, there was a significant decrease in infection in day 10 (same as in Lulo cells), probably caused by the same reasons indicated for this cell line. By contrast with Lulo cells, promastigote-like forms were not observed inside parasitophorous vacuoles in J774 cells, suggesting that these events were observed during stages following parasite transformation to amastigote form, after a relatively prolonged intracellular pathogen penetration time had passed. However, in spite of $L$. chagasi infection percentages being higher in the $\mathrm{J} 774$ line than in Lulo cells, it can be stated that reverse differentiation to promastigotes on seeding both cells in NNN medium and incubating them at $26^{\circ} \mathrm{C}$ was obtained in less time in Lulo than in $\mathrm{J} 774$ and thus final parasite population density did not reveal significant differences between the two cell lines. It is probable that maintaining some intracellular parasites as promastigote-like forms in Lulo facilitated their rapid exit from cells on being seed in NNN medium and parasite growth and replication thus occurred in less time.

The present work has shown L. chagasi interaction with cells derived from $L$. longipalpis (the main vector for this parasite in its natural environment) as well as the development of its biological cycle and intracellular replication, suggesting that these cells and (in the future) other cell cultures obtained from phlebotomine sand fly vectors could be considered as alternative models for studying multiple in vitro interaction events occurring between parasites from the Leishmania genus and sand fly vectors.

\section{ACKNOWLEDGEMENTS}

To Dr María Leonor Caldas of the National Institute of Health of Colombia, laboratory of electron microscopy, for her collaboration with electron microscopy techniques used in this work. Also, to Jason Garry for reading and correcting the manuscript.

\section{REFERENCES}

Aikawa M, Hendricks LD, Ito Y, Jagusiak M 1982. Interactions between macrophagelike cells and Leishmania braziliensis in vitro. Am J Pathol 108: 50-59.

Bates PA 1994. Complete developmental cycle of Leishmania mexicana in axenic culture. Parasitology 108: 1-9.

Bates PA, Tetley L 1993. Leishmania mexicana: induction of metacyclogenesis by cultivation of promastigotes at acidic pH. Exp Parasitol 76: 412.

Bates PA, Robertson CD, Tetley L, Coombs GH 1992. Axenic cultivation and characterization of Leishmania mexicana amastigotes-like forms. Parasitology 105: 193-202.

Bosque F, Milon G, Valderrama L, Saravia NG 1998. Permissiveness of human monocytes and monocyte-derived macrophages to infection by promastigotes of Leishmania (Viannia) panamensis. J Parasitol 84: 1250-1256.

Chang KP 1978. Leishmania infection of human fibroblasts in vitro: absence of phagolysosomal fusion after induced phagocytosis of promastigotes, and their intracellular transformation. Am J Trop Med Hyg 27: 1084-1096.

Chang KP 1979. Leishmania donovani: promastigote-macrophage surface interactions in vitro. Exp Parasitol 48: 175-189.

Chang KP, Dwyer DM 1978. Leishmania donovani: hamster macrophage interactions in vitro: cell entry, intracellular survival and multiplication of amstigotes. J Exp Med 147: 515-530.

Corredor A, Gallego JF, Tesh RB, Morales A, Carrasquilla CF, Young DG, Kreutzer RD, Boshell J, Palau MT, Caceres E, Pelaez D 1989. Epidemiology of visceral leishmanisis in Colombia. Am J Trop Med Hyg 40: 480-486.

Corredor A, Kreutzer RD, Tesh RB, Boshell J, Palau MT, Caceres E, Duque S, Pelaez D, Rodriguez G, Nichols S, Hernandez CA, Morales A, Young DG, Ferro de Carrasquilla C 1990. Distribution and etiology of leishmanisis in Colombia. Am J Trop Med Hyg 42: 206-214.

Corte-Real S, Santos CB, Meirelles MNL 1995. Diferential expression of the plasma membrane $\mathrm{Mg}^{2+}$ ATPase and $\mathrm{Ca}^{2+}$ ATPase activity during adhesion and interiorization of Leishmania amazonensis in fibroblasts in vitro. J Submicros Cytol Parasitol Pathol 27: 359-366.

Dedet JP, Ryter A, Vogt E, Hosu P, Pereira da Silva L 1983. Uptake and killing of Leishmania mexicana amazonensis amastigotes by human skin fibroblasts. Ann Trop Med Parasitol 77: 35-44.

Duque S, Tesh RB, Peláez D, Corredor A 1988. An in vitro method for long-term maintenance of Leishmania donovani chagasi. Trans R Soc Trop Med Hyg 82: 234-235.

Fampa P, Correa-da-Silva, Lima DC, Oliveira SMP, Mota MCM, Saraiva EMB 2003. Interaction of insect trypanosomatids with mosquitoes, sand fly and the respective insect cell lines. Int J Parasitol 33: 1019-1026.

Grace TDC 1962. Establishment of four strain of cells from insect tissue grow in vitro. Nature 195: 788-789.

Grimaldi G, Tesh RB 1993. Leishmaniases of the new world: current concepts and implications for future research. Clin Microbiol Rev 6: 230-250.

Hendricks LD, Wood DE, Hajduck ME 1978. Haemoflagellate: commercially avaible liquid media for rapid cultivation. Prasitology 76: 309-316.

Hérvas-Rodriguez J, Mozos E, Méndez A, Pérez J, GómezVillamandos JC 1996. The Leishmania infection of canine skin fibroblasts in vitro. Vet Pathol 33: 469-473.

Hodgkinson VH, Soong L, Duboise SM, McMahon-Pratt D 1996. Leishmania amazonensis: cultivation and characterization of axenic amastigote-like organisms. Exp Parasitol 83: 94-105.

Hunter KW, Cook CL, Hensen SA 1982. Temperature-induced in vitro transformation of Leishmania mexicana. I. Ultraestructural comparison of culture-transformed and intracellular amastigotes. Acta Trop 39: 143-150.

Leibovitz A 1963. The growth and maintenance of tissue-cell cultures in free gas exchange with the atmosphere. Am J Hygiene 78: 173-80. 
León LL, Soares MJ, Temporal RM 1995. Effects of temperature on promastigotes of several species of Leishmania. $J$ Eukaryot Microbiol 42: 219-223.

Lonardoni MVC, Russo M, Jancar S 2000. Essential role of platelet-activiting factor in control of Leishmania (Leishmania) amazonensis infection. Infect Immun 68: 6355-6361.

Looker DL, Martinez S, Horton JM, Marr JJ 1986. Growth of Leishmania donovani amastigotes in the continuous human macrophage cell line U937: studies efficacy and metabolism. J Infect Dis 86: 323-327.

Mattock NM, Petters W 1975. The experimental chemotherapy of leishmaniasis. I: Techniques for the study of drug action in tissue culture. Ann Trop Med Parasitol 69: 349-356.

Pan AA 1984. Leishmania mexicana. Serial cultivation of intracellular stages in a cell-free medium. Exp Parasitol 58: 72-80.

Papadimitriou JM, Ashman RB 1989. Macrophages: current views on their differentiation, structure, and function. $U l$ trastruc Pathol 13: 343-372.

Pearson RD, Romito R, Symes PH, Harcus JL 1981. Interaction of Leishmania donovani promastigotes with human monocyte-derived macrophages: parasite entry, intracellular survival, and multiplication. Infect Immun 32: 1249-1253.

Pelletier I, Hashidate T, Urashima T, Nishi N, Nakamura T, Futai M, Arata Y, Kasai K, Hirashima M, Hirabayashi J, Sato S 2003. Specific recognition of Leishmania major poly-betagalactosyl epitopes by galectin-9: possible implication of galectin-9 in interaction between $L$. major and host cells. $J$ Biol Chem 20: 22223-22230.

Pessotti JH, Zaverucha Do Valle T, Corte-Real S, Conçalves da Costa SC 2004. Interaction of Leishmania (L.) chagasi with the vero cell line. Parasite 11: 99-102.

Pimenta PF, Saraiva EM, Sacks DL 1991. The comparative fine structure and surface glycoconjugate expression of three life stages of Leishmania major. Exp Parasitol 72: 191-204.

Prina E, Abdi SZ, Lebastard M, Perret E, Winter N, Antoine JC 2004. Dendritic cells as host cells for the promastigote and amastigote stages of Leishmania amazonensis: the role of opsonins in parasite uptake and dendritic cell maturation. $J$ Cell Sci 15: 117: 315-325.
Ralph P, Prichard J, Cohn M 1975. Reticulum cell sarcoma: an effector cell in antibody-dependent cell-mediated immunity. J Immunol 2: 898-905.

Rey G, Ferro C, Bello F 2000. Establishment and characterization of a new continuous cell line from Lutzomyia longipalpis (Diptera: Psychodidae) and its susceptibility to infections with arboviruses and Leishmania chagasi. Mem Inst Oswaldo Cruz 95: 103-110.

Saar Y, Ransford A, Waldman E, Mazareb S, Amin-Spector S, Plumblee J, Turco SJ, Zilberstein D 1998. Characterization of developmentally-regulated activities in axenic amastigotes of Leishmania donovani. Mol Biochem Parasitol 95: 9-20.

Sacks DL, Kamhawi S 2001. Molecular aspects of parasitevector and vector-host interactions in leishmaniasis. Annu Rev Microbiol 55: 453-483.

Sacks DL, Hieney S, Sher A 1985. Identification of cell surface carbohydrate and antigenic changes between noninfective and infective developmental stages of Leishmania major promastigotes. J Immunol 135: 564-569.

Sacks DL, Saraiva EM, Rowton E, Turco SJ, Pimenta PF 1994. The role of the lipophosphoglycan of Leishmania in vector competente. Parasitology 108: 55-62.

Saraiva EM, Pimenta PF, Brodin TN, Rowton E, Modi GB, Sacks DL 1995. Changes in lipophosphoglycan and gene expression associated with the development of Leishmania major in Phlebotumus papatasi. Parasitology 111: 275-287.

Schwartzman JD, Pearson RD 1985. The interactions of Leishmania donovani promastigotes and human fibroblasts in vitro. Am J Trop Med Hyg 34: 850-855.

Tanner CE 1996. Short analytical review. Immunobiology of visceral leishmaniasis. Clin Immunol Immunophathol 78: 105-111.

Zilberstein D, Shapira M 1994. The role of $\mathrm{pH}$ and temperature in the development of Leishmania parasites. Annu Rev Microbiol 48: 449-470.

Zilberstein D, Blumenfeld N, Liveanu V, Gesptein A, Jaffe CL 1991. Growth at acidic $\mathrm{pH}$ induces an amastigote stagespecific protein in Leishmania promastigotes. Mol Biochem Parasitol 45: 175-178. 